\title{
Em busca do perdão: reflexões sobre a concessão da remissão régia à luz do processo penal português medieval (séc. XV)
}

Beatris dos Santos Gonçalves*

Resumo: $\mathrm{O}$ presente estudo visa à análise das possibilidades e dos obstáculos quando da busca do perdão régio por um ou mais súditos acusados da prática de algum crime em finais da Idade Média portuguesa. Tal discussão nortear-se-á pelas previsões legais estabelecidas nas Ordenações Afonsinas (séc. XV), no âmbito do processo penal, a fim de ser observada a dinâmica que envolvia a justiça monárquica e os que almejavam obter reintegração social através da negociação de sua remissão junto ao rei. Por tal feito, defender-se-á a hipótese de que o exercício da concessão do perdão contribuiu para o processo de afirmação do poder régio e funcionou como um importante elemento na construção de um reino mais centralizado e fortalecido.

Palavras-chave: História de Portugal. Justiça Medieval. Cartas de Perdão.

\section{Introdução: Noções Propedêuticas}

Em fins da Idade Média, Portugal, sob o reinado da Dinastia de Avis, vivenciava momentos de transição em meio às sequelas da crise dos séculos XIV e XV e aos anseios de colocar em prática o projeto de centralização política idealizado pelos reis avisinos (notoriamen-

\footnotetext{
* Pós-doutorado em andamento na Universidade Federal Fluminense. Professora nas universidades: Cândido Mendes e UniLaSalle. E-mail: beatrisgoncalves@outlook.com.
} 
Em busca do perdão: reflexões sobre a concessão da remissão régia...

te nos reinados de D. Afonso V e D. João II). Sabendo-se que o estabelecimento e a manutenção de um reino fortalecido e ordenado e em conformidade com os desideratos aglutinadores do rei somente seria possível pela mútua responsabilidade e colaboração que deveria envolver reis e súditos, o monarca deveria se empenhar na defesa e no desenvolvimento do território e de seus domínios; e seus súditos deveriam contribuir para essa prosperidade por meio do exercício adequado de suas funções e da obediência ao rei e às suas leis.

Neste diapasão, o dever de obediência se tornou imprescindível, na medida em que essa atitude não era somente benéfica para manter o equilíbrio do reino, mas também para conservar a vivência em comunidade, consolidando um contrato firmado entre os indivíduos e seu soberano, ainda que a fragilidade deste fosse notória e a fidelidade deste "acordo" fosse facilmente rompida".

O direito foi utilizado pelos reis para estabelecer a legitimidade dos princípios que deveriam ser seguidos pela cristandade durante sua administração, sendo o instrumento institucionalizado mais importante de controle social, haja vista que por seu intermédio o poder régio se manifestava formalmente de maneira mais eficaz pela força da coação, pela imposição da obediência e pelo dever de beneficiar.

O "benefício", manifestado na forma de caritas, ou de outro tipo de auxílio, também podia ser representado pelo ato régio de agraciar certos súditos que porventura tivessem caído na criminalidade, ou seja, que por algum motivo tivessem infringido as leis penais. Numa atitude misericordiosa, ficava a cargo do rei remitir a ofensa de seus súditos e reconciliá-los consigo e com a sociedade. Assim, legitimado pelo direito natural e divino, o rei exercia a justiça a fim de manter a ordem e de socorrer os que se encontravam fora da lei, estendendo às margens sua graça e mercê, expressando sua função social perante o reino.

\section{Perdão como um ato régio}

O caráter remissível dos "erros" que, a priori, pertencia à esfera eclesiástica, passou a compartilhar com o rei esse princípio cristão. A 
possibilidade de redimir colocou o monarca numa posição de privilégio e autoridade diante dos súditos e, assim como Deus, que julga, condena, mas que também perdoa, o monarca passou a se favorecer do indulto ao torná-lo o mais importante elemento da justiça régia.

Paul Ricoeur (2008, v.1, p. 196), em suas reflexões, adverte que a intenção do perdão não se constitui em apagar da memória, no esquecimento, mas sim em anular um determinado débito. O perdão seria, portanto, “[...] uma espécie de cura da memória, o acabamento de seu luto; liberta do peso da dívida, a memória fica liberada para grandes projetos. O perdão dá fruto à memória”. Contudo, a concessão do perdão régio funcionava como instrumento de obtenção de outros objetivos que o rei postulava atingir, a exemplo de:

[...] contornar as suas limitações no que tange à máquina da justiça (preparação de muitos corregedores, ouvidores, meirinhos, juízes e tabeliães); dificuldades em recrutar e sustentar guardas, carcereiros, carrascos; inexistência ou acentuada degradação das cadeias e conflitualidade entre diversos ordenamentos jurídicos, ordenações do Reino, direito comum, direito canônico, forais, posturas camarárias, direito consuetudinário. Como também reconduzir à esfera da soberania régia e reintegrar nas solidariedades familiares, locais e profissionais aqueles que um crime empurrava para uma perigosa errância, caminho privilegiado para a marginalidade. Além de favorecer a ligação pessoal entre súdito e soberano a um nível de certo modo populista. E por último garantir o fornecimento de homens que eram utilizados nas galés, como soldados nas diversas guerras e como povoadores nas áreas despovoadas e garantir o recolhimento de boa soma de reais brancos para a arca da piedade (MARQUES, 1997, p. 272).

O propósito agregador que estava presente no projeto régio de construção do reino motivou a perseguição por um ideal de paz que devia ser percebido nas feições do "bom súdito", visto ser a passividade uma virtude prioritária em seu comportamento. Desse modo, “[...] a justiça oficial, a dos juízes que impõem o poder, começ[ou] a tornar-se efetiva garantia de paz (GAUVARD, 2002, v. 
Em busca do perdão: reflexões sobre a concessão da remissão régia...

2, p. 61)". Com isso, passou o ato de julgar a expressar a "força do direito 2 ", e tem seu propósito fundamentado "[...] mais na paz social do que na segurança (RICOEUR, 2008, p. 180)”.

Em termos conceituais, compreende-se a paz como uma relação isenta de conflitos, que "[...] surge como a reconciliação de dois elementos: a diversidade das entidades a que se refere e a ausência de violência. O primeiro meio de conjugar estes dois aspectos é a ordem, mediante a qual cada elemento vem ocupar o lugar que lhe compete (MANIN, 1985, p. 274)". Assim, a paz e a ordem estavam intimamente associadas à justiça e esta ao bom governo.

O bom governo é também aquele que faz reinar a religião, isto é, que permite à Igreja exercer seu apostolado. [Visto que] [...] os soberanos se tornam o braço secular da Igreja, ele deve colocar-se a serviço desta a fim de que não haja heréticos na cidade e de que nela se propaguem a fé e a devoção. [...] A cidade medieval foi, [portanto], um campo de experiências sociais e políticas (LE GOFF, 1998, p. 102).

Nesse sentido, em busca da ordem e da paz, o rei buscava agir "[...] como pastor e pai dos súditos, que se fazia mais amar do que temer, embora não fosse deixar impunes os crimes (CARDIM, 2000), haja vista que a certeza do perdão motivava a prática de delitos, como afirmou Trevor Dean (2006, p. 20). Logo, excessiva clemência podia ser perigosa e encorajadora do crime.

A justiça do rei deveria ser, portanto, temida e respeitada, mas jamais representar desesperança. Disposto a apreciar a situação de todos os que até ele recorriam em busca de sua misericórdia, o rei, por sua virtude, deveria "[...] estar sempre pronto para salvar, mais do que para condenar (BRAGA, 2007, p. 15)". Assim, como advertia Diogo Lopes Rebelo (1951, p. 91-93), era o soberano obrigado, por sua função, a determinar "[...] a pena ao pecador, pela misericórdia tempera a pena do pecado, para em justo equilíbrio umas coisas corrigir com equidade e outras perdoar com compaixão". A remissão era, assim, essencial para a política de conciliação que os reis avisinos primavam por empregar, intermediando a necessidade de punir e beneficiar. Mas, para buscar socorro nas mãos redentoras do rei, longo, moroso e caro era, por vezes, o processo da justiça.

Anos 90, Porto Alegre, v. 20, n. 38, p. 151-179, dez. 2013 


\section{O Processo Criminal}

Matéria recepcionada mormente pelo Livro V das Ordenações do Reino, juntamente com questões referentes ao direito penal, em que pese questões processuais estarem diluídas também em outros livros, a exemplo do I e III, o processo criminal experimentado em território português nos idos de quatrocentos será analisado a partir do previsto nas Ordenações Afonsinas, consideradas a primeira compilação jurídica oficial que se estabeleceu em Portugal, sendo elaboradas desde o primeiro quartel do século XV, tendo sido concluídas em 1446 e entrado em vigor entre 1446 e 1454. Nesse sentido, tal legislação foi somente finalizada quase cinquenta anos depois, na época em que D. Afonso V havia alcançado a maioridade, e, em sua homenagem, esta obra foi por seu nome reconhecida.

As Ordenações Affonsinas representam os esforços de tres reinados successivos para coordenar a legislação e dar-lhe unidade, significando ao mesmo tempo a decadencia do direito local e o progressivo desenvolvimento da auctoridade do rei. O conhecimento dos direito inherentes á soberania não se foi buscar ao estudo dos antigos usos do reino, mas sim á lição do direito romano (BARROS, 1945, p. 134).

O processo criminal, como também o civil, reformou-se ao longo dos séculos XIV e XV, alcançando destaque na segunda metade deste último, no sentido de contribuir com melhorias para a justiça. Dentre as mudanças ocorridas, destacavam-se a maior brevidade dos pleitos (mesmo assim ainda não era célere) e a maior legitimidade conferida à prova documental, em detrimento da testemunhal.

Outrossim, houve a definição de crime público, fruto do empenho do poder central em rogar cada vez mais a prerrogativa do exercício da justiça, evitando a vingança privada. Os recursos foram mais bem regulamentados e a prisão arbitrária foi coibida.

Tais "progressos", em matéria de processo, foram produto do fortalecimento das legislações centrais em detrimento das locais, fato que possibilitou a ampliação da jurisdição régia como o exercício mais amplo da justiça, e o maior rigor sistemático, ao estabelecer critérios 
Em busca do perdão: reflexões sobre a concessão da remissão régia...

e padrões para os delitos e as penas. A partir de então, a legislação passou a organizar o processo e os modos de execução da justiça ${ }^{3}$.

O processo criminal, de rito preestabelecido, formal e predominantemente escrito, era iniciado por queixa do ofendido ao tabelião, podendo ser a querela ${ }^{4}$ apresentada por qualquer pessoa do reino, nos casos previstos no Título LVIII \$13 das Ordenações Afonsinas (1999, Livro V, p. 219-220):

Se alguum querellar d'outro, que renegou de DEOS, e de Santa Maria, ou que he treedor, ou erege, ou roubou em estradas, ou matou, ou jouve com molher d'ordem, ou que cometeo peccado de incesto, ou forçou virgem, ou outra molher que nom for virgem, ou he sudomitigo, ou alcouéta, ou que ferir ou doestar aquel, que tem Officio de Justiça, ou no Officio ou pollo Officio, ou que fez falsidade, ou que he sorteiro, ou feiticeiro, ou adivinhador, ou que queimar ou poser fogo em paaẽs, ou em vinhas, ou em outras cousas á cinte pera fazer dampno, ou furtar, ou curtar arvores alheas, que dem fruito; nos quaees casos mandamos, que se lhes for querellado, e jurada querela, e nomeadas testemunhas per qualquer do Povoo [...].

D. Afonso $\mathrm{V}$ advertia aos seus funcionários quanto ao registro exato das queixas que até estes chegavam, alertando que não houvesse qualquer acréscimo ou interferência ao que estava sendo declarado, segundo o previsto no Título LVIII \ 11 do Livro V das Ordenações Afonsinas que instruía os casos em que se devia prender 0 malfeitor, e poer contra elle feito polla Justiça, e appellar pera E/R:

PRIMEIRAMENTE mandamos e defendemos a todollos Taballiaaẽs, que nas querellas, que tomarem, nom escrepvam outras razooens nem palavras, nem enadam mais, que aquello que as partes differem, escrepvendo o feito pelo guisa que o differem, e mais nom; e qualquer Taballiom, que o contrario fezer, perca logo ho Officio, e seja preso ataa nossa mercee, pera the mandarmos dar pena de falso, ou outra pena, qual nossa mercee for (ORDENAÇÕES Afonsinas, 1999. Livro V, p. 219).

Anos 90, Porto Alegre, v. 20, n. 38, p. 151-179, dez. 2013 
No entanto, para conseguir alguma queixa ${ }^{5}$, era preciso incentivar os delatores. Como ressalta Jacques Chiffoleau (1984, p. 262), "[...] é fácil imaginar os inconvenientes de um tal sistema, em que a atração do lucro e o desejo de vingança podem multiplicar as denúncias". E tal fato se sucedeu. Muitos foram os indivíduos que se dirigiram à justiça régia por terem sido apontados como criminosos ${ }^{6}$.

Se, contudo, a queixa apresentada fosse improcedente, o acusador deveria pagar "fiança às custas" e indenizar o acusado, sendo esta uma forma de evitar tais abusos e injustiças. Essa regra foi prevista no Título LII \4, que determinava que se o queixoso não provasse a acusação deveria ser condenado nas custas do processo e por isso devia apresentar com a queixa os fiadores responsáveis ou obrigar-se por juramento a pagá-las.

[...] ante que seja recebida a tal acusaçom ou demanda, deve a dar primeiramente fiadores abonados aas custas, em que for comdepnado; e em outra guisa nom seja recebido aa dita demanda, ou acusaçom. E se elle jurar, que nom tem, nem pode aver os ditos fiadores, obrigue-se por juramento pagar ao Autor as custas, em que for condapnado [...] (ORDENAÇÕES AFONSINAS, 1999, Livro V, p. 184).

Os oficiais régios deveriam estar atentos à malícia de muitas denúncias, feitas no sentido de alcançar alguma vantagem ou feitas pelo prazer de prejudicar alguém. Desde a época de D. Dinis que os juízes e tabeliães eram alertados quanto a essa prática. Confirmando tal observação, determinou em seu tempo D. Afonso V que, caso o juiz percebesse que o querelante "[...] he malicioso, ou revoltoso, ou useiro de fazer taaes querellas e accusaçooẽs, ainda que aja per que corregua, e pague as custas, dê-lhe mais hũa pena arbitraria, qual vir que merece [...]" (ORDENAÇÕES AFONSINAS, 1999, Livro V, p. 110).

Assim, para que falsas delações fossem evitadas, as querelas eram formalizadas perante o tabelião, e somente com a ratificação da queixa apresentada por meio de testemunhas nomeadas pelo acusador e de querela jurada. Nesta, era preciso que ambos os envolvidos na lide, quais sejam, autor e réu, fizessem o juramento. 
Em busca do perdão: reflexões sobre a concessão da remissão régia...

[...] o Autor jurará, que naõ move esta demanda com tençaõ maliciosa, mas por entender, que tem justa rezam pera a mover, e proseguir ate fim; e bem assy o Reo jurará, que justamente entemde de defemder esse preito, e naõ aleguará, nem provará em elle cousa alguma per malicia, ou emguano, mas que verdadeiramente se defenderá sempre até fim do preito, a salvo de sua consciencia (ORDENAÇÕES AFONSINAS, 1999, Livro III, p. 135).

Em caso de recusa de prestar o referido juramento, se fosse autor, perderia toda a ação e, se fosse réu, seria condenado. De qualquer modo, somente após as promessas feitas e as testemunhas apresentadas que se procedia, então, à prisão do acusado ${ }^{7}$, salvo se aquele que o denunciou tivesse com este alguma inimizade.

Não obstante, “[...] se o inmigo querellar que he treedor, ou erege, ou que he culpado em moeda falsa, recebam-no á querella, nom enbargante que seu inmigo seja" (ORDENAÇÕES AFONSINAS, 1999, Livro V, p. 220). Nesses casos, portanto, devido à sua gravidade, o rei aceitava, sem exceção, a denúncia de qualquer pessoa, independentemente de sua relação com o réu.

Outro caso em que se determinava a prisão preventiva do acusado, após o juramento e a nomeação de testemunhas, era quando o querelante mostrava imediatamente "[...] feridas abertas, e sangoentas, ou laidamento no corpo [...]". Outrossim, "Se alguum querellar d'outro, que lhe fez furto, ou roubo, ou adulterio, ou lhe fez força com armas [...]" (ORDENAÇÕES AFONSINAS, 1999, Livro V, p. 119-220) do mesmo modo proceder-se-ia a detenção do acusado, segundo o que era previsto na legislação régia.

Conferidos os requisitos necessários para o recebimento da querela, juízo de admissibilidade ou condições de procedibilidade, como, a prestação de juramento e a apresentação de testemunhas, seguia-se a citação do acusado para comparecer pessoalmente em juízo, salvo nas hipóteses previstas no Livro III, Títulos I, II e III das Afonsinas.

O Título I instruía que as citações poderiam ser realizadas em quatro modalidades, quais sejam, per palha, per Porteiro, per Tabalião ou per Editos. Nos três primeiros casos, como observado no $\int$ 
13, a citação deveria ser feita somente em pessoa do citado. No entanto, em caso de ausência do acusado, deveria sê-lo citado:

[...] aa porta da Casa de sua morada, honde elle costuma morar a mor parte do anno, perante sua mulher, ou familiares de caza, ou vizinhos de sua rua, e amiguos, aos quaes deve ser requerido que notifiquem a dita Citaçaõ ao dito ausente, que a termo certo pareça perante aquelle Juiz, que o assy manda citar [...] (ORDENAÇÕES AFONSINAS, 1999, Livro III, p. 7).

Nesse mesmo Título, existia uma ressalva no $\$ 20$ quanto ao momento da citação, sinalizando que esta teria que "[...] ser feita de dia em quanto o Sol durar, e sendo feita ante que o Sol seja levado, ou depois que se poser, nom valha cousa alguũa" (ORDENAÇÕES AFONSINAS, 1999, Livro III, p. 9). O \ 21 acrescenta, ainda, uma advertência quanto às citações feitas em feriados.

A Citaçaõ, que he feita em dia feriado á honra, e louvor de DEOS, pera o citado responder em dia nom feriado, nom val, segundo direito, salvo onde se o Reo quiser absentar pera outra parte, ou a auçom do Autor fosse de tal calidade, que parecesse, se a citação assi feita em dia feriado pera responder no dia naõ feriado (ORDENAÇÕES AFONSINAS, 1999, Livro III, p. 9-10).

Após a querela ser recebida e ser dada ciência da mesma ao acusado, através da citação, deveria o querelante apresentar o libelo de acusação, sob pena de, não o fazendo, presumir-se ter desistido do processo, o qual poderia ou não ser extinto, dependendo do interesse da justiça, como observado no Título LVIIII $₫ 17$ das Afonsinas, que previa a situação em que "[...] nom querendo os querelosos acusar, ou acusando, nom querendo apellar, devem os juizes com razam aguisada poêr os feitos polla Justiça, e appellar por ella pera Nós [...]" (ORDENAÇÕES AFONSINAS, 1999, Livro V, p. 234)". Se assim fosse o caso, as acusações deveriam ser feitas 
Em busca do perdão: reflexões sobre a concessão da remissão régia...

oficiosamente pelo juiz, especialmente em episódios de cárcere privado, tirada de presos à justiça, fuga da prisão e situações afins.

A não apresentação do libelo pelo querelante podia ser explicada por alguns motivos: pelo perdão dado ao acusado, pela sensação de justiça feita com a prisão do réu, ou mesmo pela percepção de que a continuidade do processo não era vantajosa para o autor. Nesses casos, proceder-se-ia a soltura do preso por determinação judicial, pondo fim ao litígio. Contudo, se a acusação fosse grave, dar-se-ia continuidade ao processo por parte da justiça, prosseguindo uma investigação autônoma, configurada num interrogatório de testemunhas conduzido por um juiz ou um inquiridor e registrado por escrito por um tabelião, no que se chamavam inquirições devassas.

Seguia-se, assim, a apresentação de resposta do acusado, na qual deveria, desde logo, tecer as considerações meritórias e exceções pertinentes. Resolvidas as exceções, dar-se-ia a pronúncia do juiz sobre o libelo acusatório, cabendo ao acusado apresentar contestação, na qual poderia negar ou confessar a prática dos atos que lhe eram imputados. Havendo confissão, cabia logo julgamento pelo juiz, mas se a contestação fosse de negação, passava-se ao julgamento dos artigos de acusação do autor, que poderiam ser, ou não, entendidos pertinentes ${ }^{8}$. Após, procedia-se à indicação de testemunhas por ambas as partes para prova dos artigos (até trinta por cada um), devendo ser logo suscitadas as contraditas ${ }^{9}$ para impugnação por cada parte de testemunhas da parte contrária ${ }^{10}$.

Com a inquirição das testemunhas, seguia-se a abertura e publicação das inquirições para ser dada vista às partes, as quais deveriam reduzir a escrito o arrazoado do direito, podendo ainda inquirir-se alguma nova testemunha que o juiz oficiosamente quisesse designar, não sendo, então, permitido às partes produzir mais prova ${ }^{11}$.

Concluso o feito ao juiz e havendo provas suficientes da culpabilidade do réu, poder-se-ia aplicar-lhe tormentos como meio visando à ratificação das provas colhidas, até então mitigadas pela insistência do réu em jurar-se inocente.

Não era comum os privilegiados ou homens honrados, tais como fidalgos de solar, cavaleiros de espora dourada ${ }^{12}$, doutores em leis - em Direito Canônico ou em Medicina (Física) e vereado- 
res das cidades ${ }^{13}$ serem submetidos a tormentos, exceto quando a lei expressamente o permitisse, como nos casos de lesamajestade, falsidade, cárcere privado e feitiçaria ${ }^{14}$.

Um só indício suscitado sobre qualquer desses crimes podia levar até mesmo os "privilegiados" aos tormentos, a exemplo do acusado ter anteriormente confessado o fato fora do tribunal, de existir contra ele uma só testemunha ocular; ganhar sua culpa fama pública; ter se ausentado da localidade por conta do ocorrido ${ }^{15}$. Também o oposto poderia ocorrer, quando fossem os indícios "[...] tam leves e tam fracos, que todos juntos nom abastaram pera seer metido a tormento" (ORDENAÇÕES AFONSINAS, 1999, Livro V, p. 328), ficando, portanto, a decisão ao arbítrio do juiz. As confissões arrancadas por tormento tinham, todavia, algumas limitações, de modo que o acusado não podia ser condenado apenas com base neste tipo de confissão, sem sua ratificação em juízo ${ }^{16}$.

Finda a instrução e colhida informação suficiente, a instância competente pronunciava a sentença final, podendo, em alguns casos, ela própria apelar automaticamente por parte da justiça para a instância superior, comumente um dos tribunais centrais, quais sejam Casa do Cível $^{17}$ ou Casa de Suplicação. Nessa fase, era permitido ao réu clamar ao rei a concessão de seu perdão, reconhecendo ser este o único legitimado a fazê-lo por sua própria autoridade, quando nada mais o pudesse socorrer.

\section{Em Busca do Perdão}

Só por meio dessas etapas burocráticas que o acusado de um crime tinha possibilidade de apelar ao rei, requerendo uma decisão por parte do monarca, cujas variações deveriam-se ao tipo de solicitação feita, à gravidade do delito e ao interesse do rei.

Cada caso tinha sua singularidade e esta era posta à análise pelo soberano que, de modo justo e prudente, deveria dar remédio ao caso segundo sua interpretação, haja vista a lei, por mais genérica, não conseguir alcançar todas as situações possíveis ${ }^{18}$, cabendo ao rei aplicá-la com retidão, tal como prevista, ou alterá-la ${ }^{19}$, a fim de adap- 
Em busca do perdão: reflexões sobre a concessão da remissão régia...

tá-la como fosse mais probo ou melhor lhe prouvesse. O referido ato era, efetivamente, reconhecido como graça em matéria de justiça ${ }^{20} \mathrm{e}$ consolidado na forma de um documento que legitimava sua ação: a carta de perdão, que representava, por um lado, a prática jurídica do rei $^{21}$ e, por outro, a garantia de segurança do que fora acusado.

A carta de remissão, um diploma de chancelaria configurado na derradeira parte do processo, representava o ato final do rei, na ocasião em que corporificava a última instância da justiça, ou seja, a Casa de Suplicação. Esses diplomas estavam incluídos nos atos de alcance especial, ou seja, uma expressão do poder em âmbito de graça ou justiça e em prol de determinados indivíduos, entidades, comunidades, localidades ou regiões ${ }^{22}$.

Contudo, a carta de perdão ${ }^{23}$ carece de informar o processo na íntegra, possibilitando somente a reconstrução parcial do caso. Por tal motivo, importantes etapas não são possíveis de serem resgatadas pelo referido documento, a exemplo das súplicas dos que se dirigiam ao rei, das queixas das vítimas, das inquirições-devassas elaboradas pelas justiças, das sentenças e dos perdões das partes.

Não obstante as cartas de remissão possuírem percalços informativos, elas possibilitam, ainda que com certa fragilidade, "ouvir" as "vozes" quase mudas dos que se encontravam, de modo efêmero, à margem da sociedade portuguesa na Idade Média por um possível crime cometido. Acrescenta-se, ainda, que o referido diploma possibilita ao historiador remontar o dia a dia da atividade burocrática da justiça régia portuguesa medieval e de certos aspectos do cotidiano da sociedade pelos vestígios deixados nas entrelinhas desses documentos.

Em termos diplomáticos, a carta constitui-se basicamente em três partes, quais sejam, protocolo, texto e escatocolo. O protocolo porta uma intitulatio, que identifica o autor do ato e apresenta um resumo da súplica ${ }^{24}$; o escatocolo promove a conjugação dos elementos topográficos e cronológicos e dos elementos de validação (subscrições e assinaturas), consistindo nas disposições finais ${ }^{25}$. Já o texto, localizado formalmente entre o protocolo e o escatocolo, consiste na parte em que consta a decisão régia ${ }^{26}$. Sendo, pois, a carta de perdão concedida, a pessoa, antes acusada, ficava liberada da 
acusação, tendo a possibilidade de readquirir seus privilégios após ter cumprido as disposições estabelecidas no referido diploma.

Em sua esfera de atuação, o rei poderia pronunciar-se antes de qualquer sentença, de qualquer instância e de qualquer esfera, sendo ela régia, senhorial, laica ou concelhia, com a prerrogativa de suspender a execução de uma sentença já proferida ${ }^{27}$. Nesse sentido, no exercício de sua função jurídica, podia o rei manter a pena determinada pelos juízes, reduzi-la em tempo, comutá-la por outra ou, ainda, por misericórdia, conceder perdão total. Entretanto, seja qual fosse a resposta do monarca, era esta definitiva e em última instância, não cabendo mais nenhum tipo de incriminação pela mesma falta ${ }^{28}$ por parte da justiça, ficando assim o acusado liberado da culpa que sobre ele recaía. Dessa feita, “[...] entre o verdadeiro e o plausível havia espaço para a graça e o poder do soberano, e os requerentes podiam conseguir uma vida nova e reconquistar sua boa reputação" (DAVIS, 2001, p. 91).

E como os súditos percebiam esse comportamento dos reis quando em exercício da justiça? Pode-se afirmar que não eram unânimes ao avaliar a postura de seus soberanos. Essa política, tão necessária à concretização dos interesses régios, fluida em concessões e rígida em manter as leis, foi responsável por certos incômodos.

Exemplo disso foram as inúmeras reclamações que chegaram à Corte expressando a insatisfação dos povos com a severidade com que o rei punia, aplicando penas superiores às culpas. As Cortes de Leiria/Santarém de 1433 registraram queixas nesse sentido e, como resposta, solicitavam aos que se sentissem agravados por penas excessivas para que apresentassem apelação aos "[...] vereadores e procurador do lugar e obter deles a reposição da justiça; que as penas aplicadas após este recurso revert [essem] a favor dos lugares onde foram cometidos os malefícios" (AM, Pergaminho n. 19. In: SOUSA, 1990).

Seria tal protesto em relação a D. Duarte, aclamado rei neste ano? Ou em relação a seu pai, D. João I? De qualquer modo, ambos eram vistos como reis que primavam pela retidão. Mas foi com D. Afonso V que a política de flexibilização das leis e de ampliação da concessão do perdão ganhou vulto. Provavelmente tivesse sido essa mudança de atitude a responsável pelas denúncias feitas às Cortes de Lisboa, em 1459, quanto à excessiva condescendência 
Em busca do perdão: reflexões sobre a concessão da remissão régia...

com que o monarca agia, sendo, então, apresentado um "apelo" no sentido de "[...] o rei não conced[esse] perdões a criminosos comutando-lhes as penas em serviço militar de Ceuta e Alcácer; que os perdoados, no caso de reincidirem, [fossem] punidos pelo passado e pelo presente" (ANTT. Cortes M. 2, n. 14 fls. 22-39). Isso porque o perdão não era necessariamente dado de maneira individual, podendo ser concedido de maneira coletiva ou de forma geral. O chamado perdão geral, normalmente, era dado como benefício àqueles que lutaram em alguma guerra de conquista a serviço do rei.

A brandura com que o rei distribuía a justiça, do mesmo modo, era criticada por seus súditos, que percebiam como "afrouxada" a justiça régia, como observado no pedido feito nas Cortes da Guarda em 1465, para que “[...] o rei não seja fácil, como é, em conceder perdões a criminosos" (AHMP, Livro B. fls. $366 \mathrm{v}-371$ ). Tanto nas Cortes de 1459 quanto nas de 1465, acredita-se que as queixas foram dirigidas à $\mathrm{D}$. Afonso $\mathrm{V}$ que, para além da opinião dos povos, era visto por cronistas, como Rui de Pina (1901, p. 880), como amador da justyça, sendo explícito ao declarar que não soube o monarca aplicá-la de maneira indiscriminada, tendo sido mais negligente que zeloso na execução de sentenças " [...] contra grandes pessoas, as quaaes mais folgava de dissymullar ou temperar brandamente, que exucutallas com rigor."

Parece que o equilíbrio entre a severidade e a brandura com que os reis exerciam sua função veio com a regência de D. João II. Esse sentimento de desempenho probo da justiça pôde ser notado nos escritos de Rui de Pina (1950, p. 1030):

[...] mais riguroso, e severo, que piedoso; porque sem alguũa exçepçam de pessoas de baixa, e alta condiçam, foy della muy inteiro exuqutor: cuja vara, e leys nunca tirou de sua propria seeda, por asentar nella sua vontade, nem apetitos; porque as leys que a seus vassallos condanavam, nunca quis que a si mesmo asolvessem; ca seendo Senhor das leys, se fazia logo servo delas, pois lhe primeiro obedecia.

Por tais palavras, observou-se que a equidade era uma qualidade respeitante à D. João II, que fazia a justiça sem olhar a quem, 
segundo o cronista, não fazendo diferença de condição daquele que estava a seu julgo, pois, mesmo estando ele acima da lei, abaixo dela estava como rei obediente. Logo, se o rei era o exemplo para o reino e ele próprio se dizia submisso, a ideia que se queria passar aos seus súditos era de que, primeiramente, a lei era soberana e de que os súditos deveriam se espelhar no monarca. Diante disso, sentia-se o rei legitimado para corrigir os erros daqueles que estavam a ele submetidos, inclusive os nobres.

Isso não significava todavia que não fosse um rei misericordioso. Ele o era, por certo, segundo a cronística, e, quando agia com severidade, era para afastar os grandes males, contudo era de sua intenção mais beneficiar que punir:

Era muy justo, e amigo da justiça, e nas execuções della temperado, sem fazer differenças de pessoas altas, nem bayxas, nunca por seus desejos, nem vontade a deyxou inteiramente de comprir, e todalas leys que fazia compria tam perfeitamente, como se fora sogeyto a ellas. [...] nunca na justiça vsou de poder absoluto, nem de crueza, e muytas vezes vsaua de piedade, porem não que tirasse justiça as partes, nem em grandes crimes [...] (RESENDE, 1991, p. XVI).

A pesquisa realizada pela historiadora Manuela Mendonça (1994, p. 16) sobre a Chancelaria de D. João II, composta por 27 livros, concluiu que, de um total de 18.899 documentos pertencentes à referida Chancelaria, 8.151 eram cartas de perdão, conforme dados apresentados nos índices produzidos pelo mesmo estudo.

Segundo a historiadora, o perdão atingiu, no reinado de D. João II, valores significativos se comparados com as concessões feitas no mesmo sentido pelos monarcas que o antecederam ${ }^{29}$. Um dos possíveis motivos para tal aumento reside na explicação de Armando Luís de Carvalho Homem (1990, p. 83), que afirma ter sido o perdão bastante oneroso antes e após 1383-1385. 
Em busca do perdão: reflexões sobre a concessão da remissão régia...

\section{Gráfico 1 - Estatística de Perdões Concedidos no Reinado de D. João II $^{30}$}

Relação percentual [1481-1495]

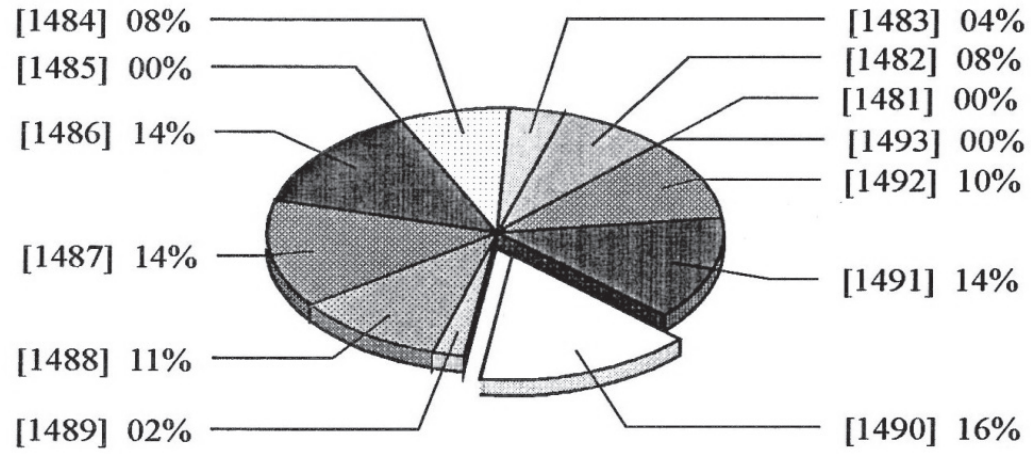

Fonte: MENDONÇA, Manuela. Chancelaria de D. João II. Op. Cit., p. 67-68.

Cartas de perdão foram distribuídas, durante o reinado de D. João II, ao longo de todos os meses do ano. Todavia, de abril a junho, a benevolência do monarca foi mais expressiva, com destaque para o mês de abril. Tal constatação feita por Manuela Mendonça corroborou com a observação de Joaquim Veríssimo Serrão (1975, p. 17), na medida em que defendeu que na época da Páscoa o rei mostrava uma faceta mais caridosa.

Segundo Garcia de Resende (1991), o próprio rei apregoava que não desampararia de sua mercê quem o pedisse em nome das chagas de Cristo, sendo o período da Páscoa bastante apropriado para colocar em prática seu gesto misericordioso. Numa dessas passagens, o cronista narrou um episódio em que, por esta época, o monarca passou por cima das burocracias da justiça e de própria boca deu a liberdade a um homem que estava para ser executado, sendo salvo pelo rogo adequado de sua esposa.

Em hũa quinta feyra dendoenças, andando el Rey correndo as Igrejas, se pos hũa molher em joelhos diante delle, e chorando muyto lhe disse: Senhor, pollo dia que oje he, e a honra das cinco chagas de Iesu Christo, peço a vossa Alteza que 
aja misericordia comigo. [...] meu marido he julgado á morte, polla morte e payxão de nosso Senhor lhe perdoay: e el Rey lhe disse: Molher, mayor cousa quisera que lhe pediras por esse por quem mo pedes, eu the perdouo liuremente: e logo dally lho mandou soltar (RESENDE, 1991, p. 140).

\section{Gráfico 2 - Número de perdões concedidos ao longo do ano $(1481-1485)^{31}$.}

$\mathrm{N}^{\mathrm{o}}$ de perdões

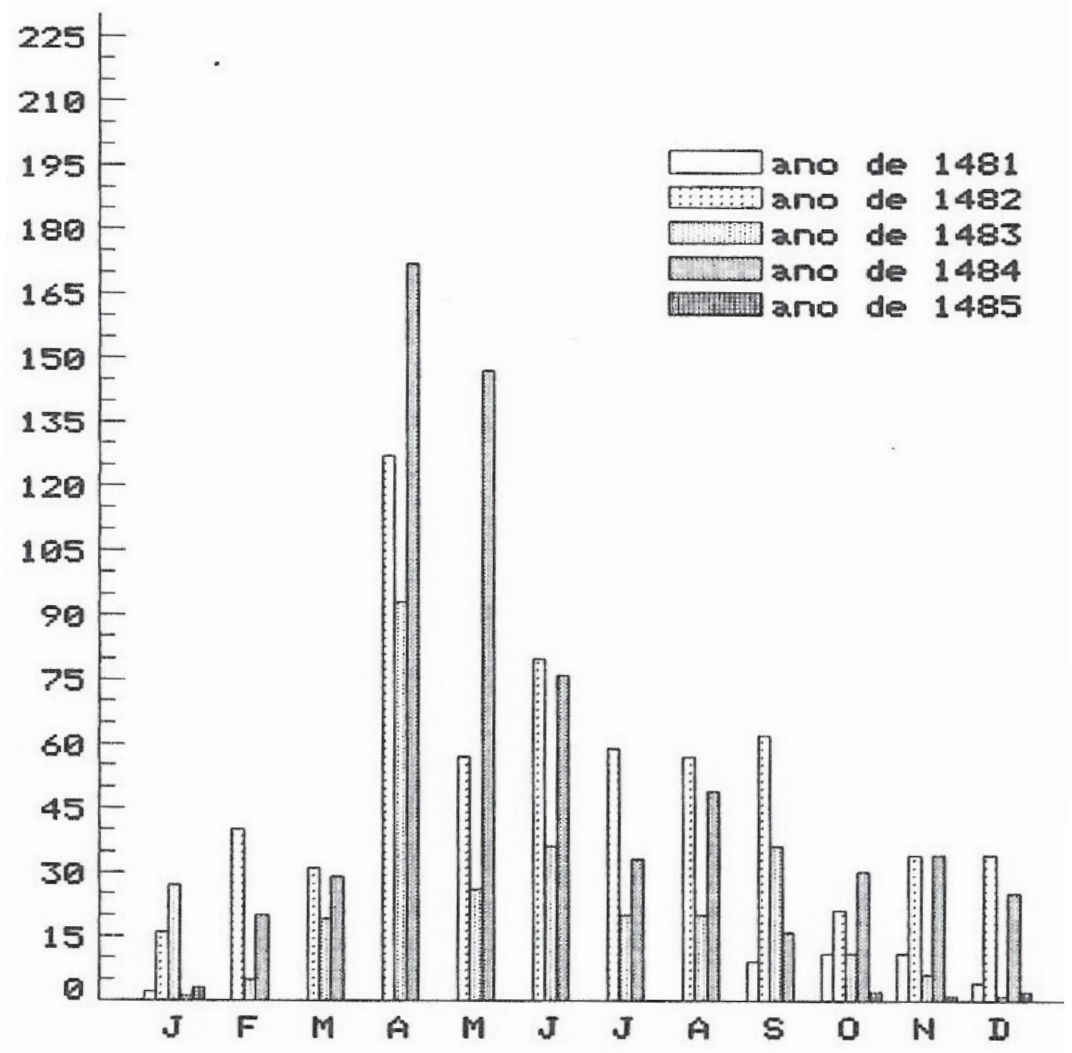

Meses do ano

Fonte: MENDONÇA, Manuela. Chancelaria de D. João II. Op. Cit., p. 294. 
Em busca do perdão: reflexões sobre a concessão da remissão régia...

\section{Gráfico 3 - Número de perdões concedidos ao longo do ano $(1486-1491)^{32}$.}

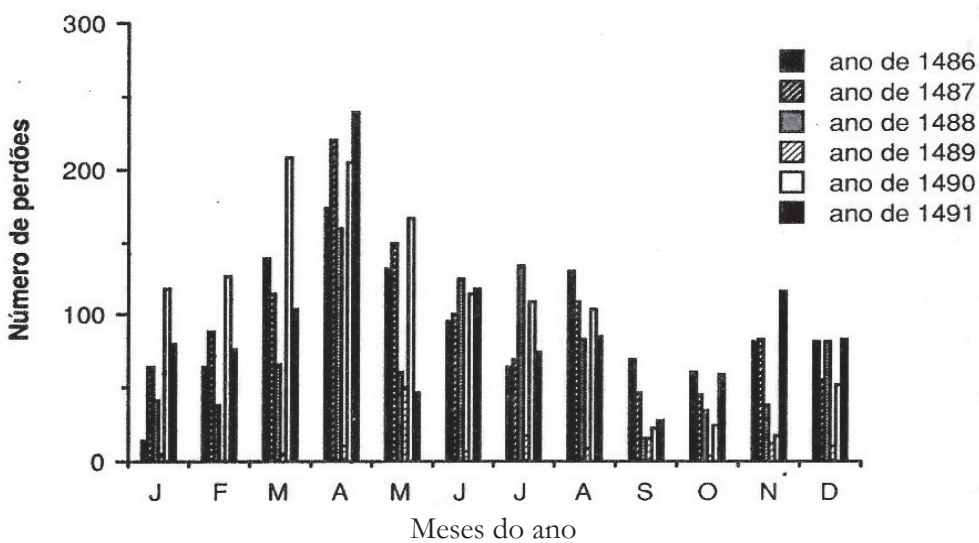

Fonte: MENDONÇA, Manuela. Chancelaria de D. João II. Op. Cit., p. 300.

De acordo com Manuela Mendonça (1995, p. 284), a explicação para o número elevado de perdões em 1482 reside no fato do rei ter sido mais benevolente por ter recentemente assumido o trono, alcançando seu auge em 1483, em tempos de Páscoa. Já o aumento de 1484 foi interpretado pela mesma historiadora como tendo sido um tipo de compensação para a consciência do monarca, por ter sido um ano após a execução do duque de Bragança, e com destaque em agosto, mês em que o duque de Viseu teve destino semelhante. Nesse sentido, D. João II manteve essa conduta de aumentar a concessão de remissões na época da Páscoa até o final de seu reinado.

A concessão régia também podia ser feita sob forma de carta de segurança $a^{33}$, comumente sendo solicitada em caso de prisão ou fuga ${ }^{34}$, representando "[...] uma espécie de habeas corpus, usado com muita frequência, aliás, na prática forense e que as Ordenações diferenciavam nitidamente da fiança, também admitida e regulada para libertar acusados" (CAETANO, 1975). Nesta perspectiva, apelava-se para "[...] sse liurar per sseu dereito daquello por que assy foy preso [...]" (ANTT. Chancelaria de D. Afonso V, liv.19, fl. 44 v; liv. 18, fl. 70 e 70 v; liv. 11, fl. 87 e liv. 15, fl. 39 v. 40). 
Para alcançar este intuito, deveria o acusado conseguir, no tempo estipulado, um instrumento de perdão da vítima ou de seus parentes, ou ser absolvido a partir de provas que pudesse juntar e trazer para a justiça. Assim, a pessoa recebia do rei o direito de ir e vir, sem ter suas atividades tolhidas ou sofrer qualquer constrangimento ${ }^{35}$, sendo assegurado " [...] o hir da dada desta nossa carta atee tres messes primeiro seguintes em o qual espaço possa andar em os nossos rregnos ssem sseer preso acabado sse apressente pessoalmente em a dicta cidade [...]" (ANT'T. Chancelaria de D. Afonso V, liv. 9, fl. $98 \mathrm{v}$ ). Entretanto, algumas cartas concediam prazos distintos, podendo ser de quinze dias, por exemplo.

Depreende-se a ideia de que o acesso mais próximo ao rei, no sentido de realizar solicitações diretas, para intervir diante dos litígios motivava tais pedidos, aproveitando a presença régia para "[...] denunciar oficiais corruptos ou desmandos de senhores, obter perdão ou segurança para pôr um ponto final num conflito ou numa dívida à justiça que se arrastavam há anos" (MORENO, 1995, p. 324). Segundo Humberto Baquero Moreno (1995, p. 324), a criminalidade apresentava menores índices nos lugares em que chegava a Corte, bem como a Corte solucionava questões e irregularidades pendentes. Diante disso, infere-se que os itinerários percorridos pela Corte iam delineando diferentes realidades por onde passavam.

Nesses termos, o rei, em sua "missão justiceira", com as respectivas obrigações e determinados limites, atuava como um " [...] harmonizador de súbditos desavindos, um conciliador de interesses díspares. [...], que exercia seu governo pela graça" (DUARTE, 1999, p. 465), sendo generoso com aqueles que até ele recorriam.

\section{A solicitação da carta de perdão}

A formalização da carta de perdão era dada por meio do perdão das partes. Para tal, o requerente deslocava-se à Corte, sendo conduzido pelo porteiro ao respectivo escrivão ${ }^{36}$, que tinha a incumbência de verificar a conformidade da documentação, se havia a petição necessária, que era o perdão das partes e, no caso de existirem mortes, se constava o perdão dos familiares e parentes 
Em busca do perdão: reflexões sobre a concessão da remissão régia...

até o quarto grau ${ }^{37}$. Se a documentação a ser entregue estivesse devidamente correta, era levado ao despacho do Desembargo e, posteriormente, encaminhado ao Chanceler.

Prosseguia-se o pagamento dos emolumentos na Chancelaria e, por fim, em sua terra, o peticionário entregava a carta ao juiz para verificá-la. O pagamento do perdão era, portanto, realizado sob a forma de multa, à Arca da Piedade ${ }^{38}$, sendo recebidas as quantias pelo esmoler ${ }^{39}$. Como funcionário da Corte, cabia-lhe controlar os dinheiros destinados às esmolas do rei, provenientes nomeadamente de multas, quer as que se achavam previstas nas Ordenações do Reino, quer as que eram pagas pelos acusados pela comutação das penas ou pelo perdão régio. Ao fim, as custas pagas eram lançadas em receita pelo escrivão da Corte.

Entretanto, o caminho que levava ao perdão régio em muitos casos era árduo. Esse processo era custoso não somente pela morosidade da justiça, mas, antes, em termos financeiros, por dificultar o acesso irrestrito à remissão, prejudicando aqueles que não tinham condições até mesmo de chegar à Corte, nem de cumprir os necessários trâmites da justiça, como a aquisição de documentos, o pagamento de advogados, tabeliães, entre outros ${ }^{40}$.

Depreende-se disso a análise de Claude Gauvard (2010, p. 69), ao inferir que "[...] o pedido de uma graça é um sério problema que põe em causa a vida e as finanças do suplicante, dos seus parentes, dos seus amigos [...]". Assim, a justiça, apesar de tocar a todos, ainda que de maneira distinta, na ocasião do cumprimento dos deveres para com o reino não agraciava a todos com seus privilégios, visto que, nesse caso, o direito era uma realidade de poucos.

Além das questões burocráticas, para que o solicitante tivesse mais chances de alcançar o almejado perdão, era preciso convencer o rei. No intuito de persuadir o monarca, era necessário explicar sua solicitação, expondo os fatos que motivaram sua denúncia, por meio de argumentos pertinentes e comoventes, que pudessem justificar o perdão régio. Nesse sentido, o impetrante podia utilizar, por vezes, critérios particulares para tornar a narrativa mais atraente ou convincente, fato que podia corromper a versão original, comprometendo a "verdade" do ocorrido. 
Em muitos casos, o acusado entrava com um discurso ${ }^{41}$ negatório, refutando o feito pelo qual tinha sido acusado, afirmando inocência. Contudo, “[...] buscar misericórdia em lugar de justiça tinha lá seus riscos. Afinal, o requerente confessava abertamente que cometera o ato; não havia mais chance de alegar que na verdade estava em outro lugar [...]". ${ }^{42}$ Assim, em certos casos, para que o perdão fosse alcançado, era necessário confessar seus atos e, de maneira submissa, clamar pela indulgência régia.

Mostrando humildade e arrependimento, o acusado deveria se esforçar para convencer o rei de que não representava uma ameaça à sociedade. Fato é que, para que o rei desse a atenção necessária ao pedido, era preciso que o relato fosse bem elaborado, provando ao rei que era merecedor de sua graça e mercê.

\section{Imagem - O preço do perdão ${ }^{43}$}

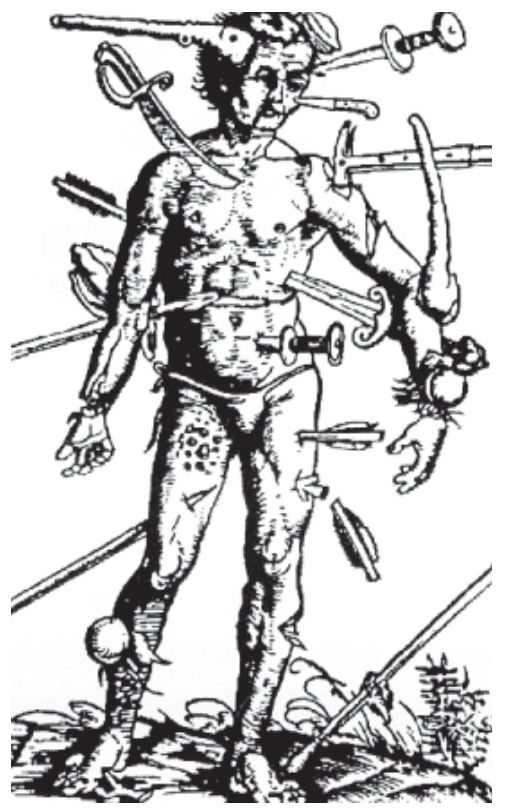

LEGENDA

1. Ferida na cabeça - 1.000 reais; 2. Lança pelo corpo - 1.000 reais; 3. Ferida por qualquer parte do corpo, sem ser de lança, e sem aleijão - 800 reais; 4. Dedo da 
Em busca do perdão: reflexões sobre a concessão da remissão régia...

mão direita ou esquerda - 3.000 reais (ou mais); 5. Ferida pelo rosto que deixe marca - 2.000 reais (ou mais); 6. Aleijão da mão direita - 10.000 reais (ou mais); 7. Aleijão da mão esquerda - 8.000 reais (ou mais); 8. Aleijão do pé direito - 8.000 reais (ou mais); 9. Aleijão do pé esquerdo - 6.000 reais (ou mais); 10. Dedo do pé esquerdo ou direito - 1.000 reais (ou mais); 11. Aleijão do braço direito - 12.000 reais (ou mais); 12. Aleijão do braço esquerdo - 10.000 reais (ou mais); 13. Aleijão da perna direita - 12.000 reais (ou mais); 14. "Quebramento" de olho (direito ou esquerdo) - 7.000 reais (ou mais); 15. "Cortamento de nariz que leve parte dele fora" - 4.000 reais; 16 . Corte de orelha - 2.000 reais (ou mais).

Fonte: Prato de cobre gravado por Hans Von Gersdorff, 1517. DUARTE, Luís Miguel. Justiça e criminalidade. Op. Cit, p. 491.

Recorria-se, neste sentido, estrategicamente a argumentos quase sempre eficazes - ser pessoa de mor qualidade, por exemplo -, ou mesmo apelava-se ao sentimental - ser pobre, de idade avançada, ter família, ignorância, viuvez, clamar pelo nome de Nosso Senhor -, buscando sempre sensibilizar o rei. E, como resposta, investido do poder que lhe cabia, o rei tinha a competência de conceder o perdão por meio de uma fórmula bem demarcada, "[...] que nossa mercee e voontade he de lhe perdoarmos como dicto he" (ANTT. Chancelaria de D. Duarte, liv. 3, fl. 38), ou, quando fosse de sua vontade, indeferir o pedido ou mesmo solicitar maiores informações, quando as julgava insuficientes.

Verossímeis ou não, as histórias relatadas nas cartas tinham a intenção de suscitar no monarca um sentimento de piedade, na tentativa de evitar uma possível reação de "vingança" encarnada numa punição rigorosa. Além disso, buscava-se uma readmissão na sociedade, haja vista que, por sua autoridade, o rei poderia resgatar seus súditos da margem, que o crime representava e conduzia, reinserindo-os ao corpus social.

\section{Considerações finais}

A organização da justiça ocupou lugar de destaque no projeto de centralização do reino português durante o século XV. Neste sentido, o reinado de Avis, a fim de impor a autoridade régia diante 
de seus súditos e dos poderes que com ele concorriam (poderes eclesiástico e senhorial) fez uso da normatização das leis através das Ordenações do Reino e do aprimoramento do aparato burocrático-jurídico que auxiliava o monarca no processo de distribuição da justiça, logrando obter, ainda que não em sua totalidade, maior controle sobre a sociedade.

Contudo, o reconhecimento do rei como a encarnação do Justo não foi sentida somente pela severidade com que as leis eram aplicadas, mas na possibilidade da remissão de seus débitos com a justiça do monarca, a fim de lograr sucesso no processo de reconciliação entre rei e súditos. Desta feita, foi através da fluidez observada na dinâmica da justiça que o jogo político encontrou seu lugar de exercício, abrindo brechas para que o monarca pudesse atuar de modo a seguir o que estava positivado ou transpor o determinado, se assim fosse mais interessante.

A manifestação desse jogo de poderes não acontecia somente em sua forma mais tradicional, de cima para baixo, quando ficava a cargo do rei perdoar ou não aqueles que apelavam à sua justiça, num ato último do processo criminal. Também se dava de baixo para cima, conforme sinalizavam as cartas de perdão, quando o solicitante buscava persuadir o monarca, fazendo-o crer ser merecedor do almejado perdão, não tendo sido poucas as vezes que o rei tomava esses "diálogos" como razão de sua graciosa decisão, fundamentando sua autoridade nas ponderações defensivas e rogatórias dos então acusados suplicantes. De todo modo, em tais movimentos, percebe-se a existência de uma rede de poderes que se formava entre o rei e seus súditos, na medida em que ambos se inseriam como participantes dessa dinâmica.

Outrossim, fez parte da propaganda política régia a ideia de que todos tinham acesso à benevolência da remissão régia, em que pese na prática ser este um processo demorado e não tão acessível a todos, haja vista as dificuldades encontradas por muitos na ocasião de juntar a documentação necessária para proceder à solicitação do perdão e, ainda, as altas quantias que envolviam o pagamento das custas do processo e as vultuosas multas cobradas a favor do rei e da Piedade. 
Em busca do perdão: reflexões sobre a concessão da remissão régia...

De todo modo, eis o propósito que aos poucos foi sendo conquistado: perpetuar a memória de que só o rei poderia garantir a justiça, castigando ou beneficiando ao corporificar a última e única instância decisória com poder de remissão, proporcionando ao soberano a construção de uma imagem paternalista e aglutinadora ao fazer uso do perdão como um instrumento político, servindo como um elemento eficaz a favor da afirmação do poder régio diante do reino português.

\section{IN SEARCH OF FORGIVENESS: REFLECTIONS ON THE GRANTING OF REAL FORGIVENESS BASED ON PORTUGUESE CRIMINAL PROCESS IN MIDDLE AGES (XV CENTURY)}

Abstract: This study aims to analyze the possibilities and obstacles when seeking the royal pardon for one or more subjects accused of a crime in the late Middle Ages Portuguese. Such discussion will be guided by the legal provisions laid down in the Ordinances Alfonsine (XV century), in criminal proceedings, to be observed dynamics involving justice and monarchy which sought to obtain social reintegration through the negotiation of a remission with the king. For this feat, will defend the hypothesis that the exercise of granting pardon contributed to the process of assertion of royal power and acted as an important element in building a kingdom more centralized and strengthened.

Keywords: Portugal History. Medieval Justice. Pardon Letters.

\section{Notas}

${ }^{1}$ Importa ressaltar que a noção de contrato e acordo aqui utilizada remonta ao afirmado por Jacques Le Goff (2007, p. 104): “[...] o rei medieval foi um rei contratual". Desta feita, diferentemente dos acordos e contratos firmados depois do Iluminismo, as ações dos reis medievais em matéria de justiça eram realizadas a fim de conciliar interesses, haja vista terem jurado compromisso em relação a Deus, à Igreja e aos súditos na ocasião de sua coroação. Com isso, aparta-se qualquer anacronismo que o sentido de tais termos possa inspirar.

${ }^{2}$ RICOEUR, 2008, p. 177.

${ }^{3}$ MARQUES, 1986, p. 299.

${ }^{4}$ Distinguia-se a querela pública (aberta a qualquer do povo), a querela privada (reservada ao ofendido) e a querela oficiosa (facultada à justiça). CAETANO, 2000, p. 572. 


\section{Beatris dos Santos Gonçalves}

${ }^{5}$ DUARTE, 1989. V.1, p. 447-461.

${ }^{6}$ DUARTE, 1998, p. 460.

${ }^{7}$ DUARTE, 1999, p. 380; 571.

${ }^{8}$ ORDENAÇÕES Afonsinas, 1999. Livro III. Título LVIIII.

${ }^{9}$ As contraditas diziam respeito às qualidades das testemunhas, de modo a aferir grau de confiabilidade de seus depoimentos, influenciados por eventuais parentescos, amizades ou interesses no resultado do processo.

${ }^{10}$ ORDENAÇÕES Afonsinas, 1999. Livro III. Título LXI.

${ }^{11}$ CAETANO, 2000, p. 573.

${ }^{12}$ Aludidos em vários momentos nas Ordenações Afonsinas, tais cavaleiros eram assim referenciados para impor diferença entre os que tinham sido armados de acordo com os rituais da Ordem da Cavalaria - os que podiam usar as esporas douradas - e os cavaleiros de conthia, ou de quantia, que eram os antigos cavaleiros vilãos dos concelhos. Cf. CAETANO, 2000, p. 575.

${ }^{13}$ CAETANO, 2000, p. 573.

${ }^{14}$ ORDENAÇÕES Afonsinas, 1999. Livro V, p. 327.

${ }^{15}$ CAETANO, 2000, p. 574.

${ }^{16}$ A ratificação obedecia a limitações espaciais e temporais, de modo que a audiência deveria ser realizada em lugar distanciado daquele em que foi o réu atormentado e dias depois do tormento, quando o acusado já não estivesse sofrendo as dores e tormentos causados pelo dito feito.

${ }^{17}$ As apelações do tipo criminal de todo o reino eram feitas para a Casa de Suplicação, com exceção de Lisboa, por serem feitas para a Casa do Civil, cujo assentamento era na referida cidade.

${ }^{18}$ KRYNEN, 2009, p, 140.

${ }^{19}$ A discussão que envolve a legislação e sua aplicação prática (ou não) pode ser observada ao longo da seguinte obra: LEMESLE, 2008.

${ }^{20}$ TESSIER, 1962, p. 261-264; HESPANHA, 1982, p. 336-337.

${ }^{21}$ GÉNICOT, 1972. V. 1, p. 18.

${ }^{22}$ HOMEM, 1990, p. 47-48.

${ }^{23}$ DUARTE; FERREIRA, 1989, p. 178.

${ }^{24}$ Muito comuns eram os termos: "[...] pedindo-nos por mercê à honra da morte e paixão de Nosso Senhor Jesus Cristo que lhe perdoássemos a nossa justiça [...]". DUARTE, 1999 , p. 37.

${ }^{25}$ HOMEM, 1990, p. 49. Nas disposições finais, o rei alude: "E não fazendo ele assim [isto é, não cumprindo as condições do perdão] esta carta lhe não valha. $\mathrm{E}$ fazendo como dito é, mandamos que o não prendais nem mandeis prender nem lhe façais nem consentais ser feito mal nem outro nenhum desaguisado quanto é pela dita morte [ou fuga; ou roubo, etc.] porque nossa mercê e vontade é de lhe perdoarmos como dito é". 
${ }^{26}$ A decisão do rei normalmente mostra que "[...] querendo-lhe fazer graça e mercê à honra da morte e paixão de Nosso Senhor Jesus Cristo, temos por bem e mandamos que [...]". DUARTE, 1999, p. 37.

${ }^{27}$ DUARTE, 1999, p. 36.

${ }^{28}$ ORDENAÇÕES Afonsinas, 1999. Livro V, p. 359-360.

${ }^{29}$ MENDONÇA, 1995, p. 292.

${ }^{30}$ MENDONÇA, 1994, p. 67-68.

${ }^{31}$ MENDONÇA, 1994, p. 294.

${ }^{32}$ MENDONÇA, 1994 p. 300.

33 ORDENAÇÕES Afonsinas, 1999. Livro III, Tít. CXXII e CXXIII; Livro V, Tít. XXXXIIII, LVII e CXII.

${ }^{34}$ Nesse caso, o suspeito ou acusado podia acompanhar, em liberdade, os trâmites do seu processo.

${ }^{35}$ ORDENAÇÕES Afonsinas, 1999. Livro. III, p. 438-441.

${ }^{36}$ ORDENAÇÕES Afonsinas, 1999. Livro I. Título IV.

${ }^{37}$ CARVALHO, 2002, p. 25-26.

${ }^{38}$ Esta arca era um tipo de caixa, baú ou cofre, para onde era recolhido todo o dinheiro pago pelos réus como forma de redenção dos crimes ou faltas cometidas. Geralmente com várias fechaduras, cada uma das quais possuía sua chave entregue a diferentes claviculários. A Arca da Piedade era o cofre onde se guardavam os dinheiros destinados a donativos régios para obras pias. Entre estas, a redenção dos cativos, ou seja, o resgate dos portugueses aprisionados pelos infiéis, que podiam ser libertados pelo pagamento determinado pelos que estavam em posse destes, sendo avaliados por suas categorias sociais. Essa prática também era válida quanto aos infiéis cativos em Portugal. CAETANO, 2000, p. 557.

${ }^{39}$ Os esmoleres mores do reino eram os abades do mosteiro cisterciense de Santa Maria da Alcobaça. Em Portugal, a preferência provavelmente era pela posição de grandes produtores dos alcobacenses, o que, no início, a coroa portuguesa teria encarado com facilidade para um fornecimento privilegiado de esmolas régias.

${ }^{40}$ DUARTE, 1999, p. 40.

${ }^{41}$ Cf. SEGRE, 1989.

${ }^{42}$ DAVIS, 2001, p. 28.

${ }^{43}$ Prato de cobre gravado por Hans von Gersdorff, em 1517. Segundo o regimento de D. Manuel de 1517. Ilustração extraída de: DUARTE, 1999, p. 491. 


\section{Beatris dos Santos Gonçalves}

\section{Referências}

AHMP, Livro B. fls. 366 v. 371.

ANTT. Chancelaria de D. Afonso V, liv.19, fl. 44 v; liv. 18, fl. 70 e 70 v; liv. 11, fl. 87 e liv.15, fl. 39 v -40.

ANTT. Chancelaria de D. Duarte, liv.3, fl. 38.

ANTT. Cortes M.2, n.14 fls. 22-39.

ORDENAÇÕES Afonsinas. Lisboa: Fundação Calouste Gulbenkian, 1999. Livro I, III e V.

PINA, Rui de. Chronica de el-Rei D. Afonso V. Lisboa: Bibliotheca de Classicos Portuguezes, 1901.

. Croniqua Delrei Dom Joham II. Coimbra: Atlântida, 1950.

RESENDE, Garcia de. Crónica de D. João II e miscelânea. Lisboa: Imprensa Nacional - Casa da Moeda, 1991.

BARROS, Henrique da Gama. História da administração pública em Portugal nos séculos XII a XV. Lisboa: Sá da Costa, 11 v. V.1, 1945.

BRAGA, Isabel Mendes Drumond. Vivências no feminino: poder, violência e marginalidade nos séculos XV a XIX. Lisboa: Tribuna, 2007.

CAETANO, Marcello. Da justiça privada na Idade Média até o mandado de segurança. Conferência pronunciada em Porto Alegre, em 29 de agosto de 1975 na Universidade de Direito da Universidade Federal do Rio Grande do Sul.

. História do direito português (sécs. XII-XVI): subsídios para a história das fontes do direito em Portugal no século XVI. Lisboa: Verbo, 2000.

CARDIM, Pedro. O poder dos afectos. Ordem amorosa e dinâmica política no Portugal do Antigo Regime. Tese (Doutorado em História). Lisboa: Universidade Nova de Lisboa, 2000.

CARVALHO, António Eduardo Teixeira de. A chancelaria régia e os seus oficiais em 1468. Porto: Câmara Municipal de Torre de Moncorvo, 2002.

CHIFFOLEAU, Jacques. Les justices du Pape. Délinquance et criminalité dans la region d'Avignon au XIV siècle. Paris: Publications de la Sorbonne, 1984.

DAVIS, Natalie Zemon. Histórias de perdão e seus narradores na França do século XVI. São Paulo: Companhia das Letras, 2001.

DEAN, Trevor. Crime in medieval Europe 1200-1550. London: Pearson Education, 2006. 
Em busca do perdão: reflexões sobre a concessão da remissão régia...

DUARTE, Luís Miguel. A denúncia nas leis e na vida portuguesa de quatrocentos. Inquisição. Comunicaçoes apresentadas ao $1^{\circ}$ Congresso Luso-Brasileiro sobre Inquisição. Lisboa: Sociedade Portuguesa de Estudos do Século XVIII/Universitária, 1989. V.1. . Contrabandistas de gado e "passadores de cousas defesas" para Castela e "Terra de Mouros". In: Revista da Faculdade de Letras - História.V. XV-1. Porto: Universidade do Porto, 1998.

DUARTE, Luís Miguel. Justica e criminalidade no Portugal medievo (1459-1481). Lisboa: Fundação Calouste Gulbenkian, 1999.

DUARTE, Luís Miguel; FERREIRA, Maria da Conceição Falcão. Dependentes das elites Vimaranenses face à justiça no reinado de D. Afonso V. In: Separata da Revista da Faculdade de Letras. II Série. Porto: Faculdade de Letras do Porto, 1989 V. VI. GAUVARD, Claude Gauvard. “De grâce especial”. Crime, État et societé en France à la fin du Moyen Âge. Paris: Publications de la Sorbonne, 2010.

. Justiça e paz. In: LE GOFF, Jacques; SCHMITT, Jean Claude. Dicionário temático do Ocidente medieval. Bauru/São Paulo: Edusc/Imprensa Oficial do Estado, 2002. $2 \mathrm{v}$.

GÉNICOT, Léopold. Typologie des sources du Moyen Age Occidental. Turnhout, Brepolis, 1972. v. 1.

HESPANHA, António Manuel. História das instituições: épocas medieval e moderna. Coimbra: Almedina, 1982.

HOMEM, Armando Luís de Carvalho. O desembargo régio (1320-1433). Lisboa: Instituto Nacional de Investigação Científica, 1990.

KRYNEN, Jacques. L'idéologie de la magistrature ancienne. L'état de justice. France, XIII ${ }^{\mathrm{e}}$ - XX ${ }^{\mathrm{e}}$ siècle. Paris: Éditions Gallimard, 2009.

LE GOFF, Jacques. Por amor às cidades. São Paulo: Unesp, 1998. - As raizes medievais da Europa. Petrópolis: Vozes, 2007.

LEMESLE, Bruno. Conflits et justice au Moyen Agge: normes, loi et résolution des conflits em Anjou aux XI ${ }^{e}$ et XII ${ }^{\mathrm{e}}$ siècles, Paris: PUF, 2008.

MANIN, Bernard. Paz. In: ROMANO, Ruggiero (Dir.). Enciclopédia Einaudi. Antropos - Homem. Lisboa: Imprensa Nacional-Casa da Moeda, 1985. v. 5.

MARQUES, António Henrique de Oliveira. História de Portugal: das origens ao Renascimento. Lisboa: Presença, 1997.

. Portugal na crise dos séculos XIV e XV. In: SERRÃO, Joel; MARQUES, A. H. de Oliveira. Nova história de Portugal. Lisboa: Presença, 1986. v. 2. 


\section{Beatris dos Santos Gonçalves}

MENDONÇA, Manuela. Chancelaria de D. João II. Índices. Fontes documentais. Lisboa: Arquivos Nacionais/Torre do Tombo, 1994. 2 v.

. D. João II. Histórias de Portugal. Lisboa: Editorial Estampa, 1995.

MILLET, Hélène (Dir.), Suppliques et requêtes, le gouvernement par la grâce en Occident (XII $-\mathrm{XV}^{\mathrm{e}}$ siècle), Collection de l'École Française de Rome, n.130, Rome, École Française de Rome, 2003.

MORENO, Humberto Baquero. História de Portugal medievo: político e institucional. Lisboa: Universidade Aberta, 1995.

REBELO, Diogo Lopes. Do governo da república pelo rei. Reprodução fac-similada da edição de 1496. Introdução e notas de Arthur Moreira de Sá. Lisboa: Instituto para a Alta Cultura, 1951.

REIS, António Matos. Os forais antigos de Melgaço, terra de fronteira. In: Revista da Faculdade de Letras - História. II Série. V. XV-I. Porto: Universidade do Porto, 1999, p.111.

RICOEUR, Paul. O justo. São Paulo: Martins Fontes, 2008. 2v. v.1.

SEGRE, Cesare. Discurso. In: ROMANO, Ruggiero (Dir.). Enciclopédia Einaudi, Literatura - Texto. Lisboa: Imprensa Nacional-Casa da Moeda, 1989. v. 17.

SERRÃO, Joaquim Veríssimo. Itinerários de El-Rei D. João II (1481-1488). Lisboa, 1975.

SOUSA, Armindo de. As cortes medievais portuguesas (1385-1490). História Medieval 4. Porto: Instituto Nacional de Investigação Científica, 1990. 2v.

TESSIER, Georges. Diplomatique royale française Paris: Picard, 1962.

Recebido em: 30 de junho de 2013. Aprovado em: 30 de setembro de 2013. 